Apidologie, 1979, $10(1), 17-21$.

\title{
POPULATION CHANGE AND NOSEMA SPORE LEVELS IN COLONIES STARTED WITH PACKAGE BEES
}

\author{
T. LEHNERT and H. SHIMANUKI \\ Bioenvironmental Bee Laboratory, Federal Research \\ Science and Education Administration, USDA, Beltsville, Maryland 20705
}

\section{SUMMARY}

Ten colonies with yellow bees and black queens were established to determine, first, if newly emerged bees would cause a decline in nosema infection; second, the extent to which newly emerged bees would become nosematic; third, to evaluate the effect of one feeding of fumagillin at the time packages are installed, and; fourth, how long it would take for a foraging population to change from old to younger bees.

Packages of bees were each inoculated with $54 \times 10^{6}$ nosema spores. Half of the colonies were fed 3.79 liters of $50 \%$ sugar syrup containing $100 \mathrm{mg}$ fumagillin.

Only a small number of bees in the new population became infected with nosema because much of the nosema was eliminated with the death of the older bees. The increasing numbers of newly emerged bees also were responsible for the decline in percentage of bees infected with nosema. One feeding of fumagillin did not eliminate infection in the new population. The foraging population reached $50 \%$ old and new bees in about 43 days.

\section{INTRODUCTION}

Nosematosis caused by the microsporidan Nosema apis Z., can be a problem in overwintered colonies and in colonies started in the spring with package bees. There are several reasons why nosematosis reaches peak infection levels in the spring. For example, bees whose flight is restricted as in overwintered colonies, defecate in the hive, thereby spreading infectious spores to other bees. Also, in colonies started with package bees, nosema can rapidly multiply because bees are confined in packages for some time while in transit and no new bees emerge for 3-4 weeks after the bees are installed. Then if the queen becomes infected, supersedure usually occurs, which causes either loss or severe debilitation of the colony. However, MoELler (1972) showed that the percent bees infected with nosema decreases in an overwintered colony as new bees emerge in late spring, and this enables the colony to recover. 
The purpose of our test was first, to explore the dilution theory of MoELLER; second, to determine the extent to which newly emerged adult bees become nosematic; third, to evaluate the effect of one feeding of fumagillin at the time packages are installed, and fourth, to determine how long it will take for a foraging population to change from old to younger bees.

\section{MATERIALS AND METHODS}

To distinguish older (package) bees from newly emerged bees as the population changed, we started with ten $3 \mathrm{lb}$. $(1.36 \mathrm{~kg}$ ) packages of yellow bees with black queens shipped from a commercial producer. Four days before the installation, the packages of bees were each sprinkled with $54 \times 10^{6}$ nosema spores in $50 \mathrm{ml}$ of $50 \%$ sugar syrup to insure infection. The queens were released at the time of installation. Also, at that time one group of 5 colonies was fed 1 gal ( 3.79 liter) of $50 \%$ sugar syrup with $100 \mathrm{mg}$ fumagillin and the remaining 5 colonies received 1 gal ( 3.79 liter) of $50 \%$ syrup with no fumagillin.

Random samples of 20 foraging bees were then collected weekly at the entrance of each colony and examined individually for the presence of nosema spores. A hemocytometer was used to make spore counts. The numbers of yellow and black bees in the foraging sample were also recorded.

In addition, to ascertain that there was no difference in susceptibility to nosema infection in yellow and black bees, we placed 20 newly emerged yellow worker bees in each of 2 small cages (10/cage) and 20 newly emerged black worker bees in each of 2 small cages (10/cage). Bees in each cage ( 2 replicates) were fed $10^{7}$ nosema spores in $50 \%$ sugar syrup for 3 days and then $50 \%$ sugar syrup. The bees were held in an incubator at $34^{\circ} \mathrm{C}$ for 2 weeks. Then they were sacrificed and spore counts were made.

\section{RESULTS AND DISCUSSION}

The difference in spore count between yellow $\left(13.3 \times 10^{6} /\right.$ bee $)$ and black $\left(10.8 \times 10^{6} /\right.$ bee $)$ bees in the cage test was not significant.

Approximately 6 weeks after the package bees were installed, the foraging population was equally divided between yellow and black bees (Fig. 1). The peak percentage of bees infected with nosema occurred 11 days after the bees were installed, and the decline in infection paralleled the decrease in the number of yellow bees (Fig. 2). The infection in the young foraging bees never exceeded $5 \%$ (Fig. 3 ).

A single feeding of fumagillin suppressed nosema infection in the yellow bees from the original packages. Also when fumagillin was fed to the package colonies, the infection peaked at $30 \%$ of the foraging bees, in colonies not fed the antibiotic infection rose to $65 \%$ of the foraging bees. The highest average spore level in bees fed fumagillin was $3.5 \times 10^{6}$ spores per bee, and this level prevailed for only 1 week. In colonies not fed fumagillin, the spore level averaged $15.27 \times 10^{6}$ spores per bee and this level prevailed 4 successive weeks. 


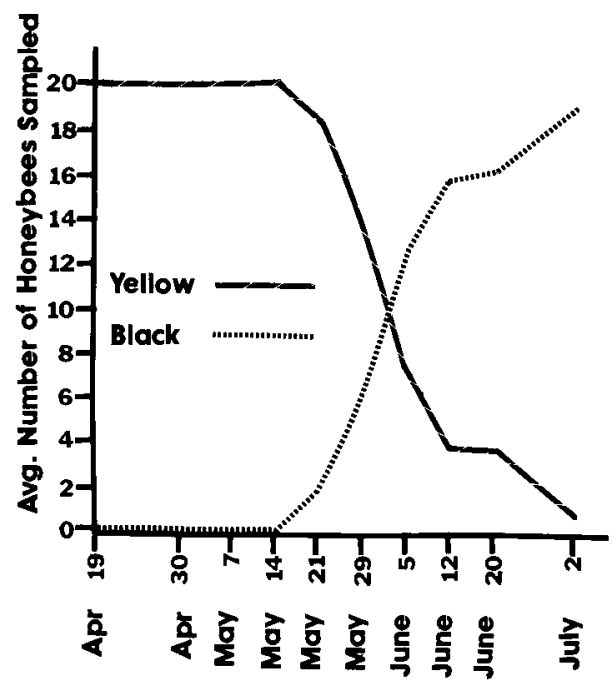

FIG. 1. - Change in adult population from yellow to black based on a 20-bee foraging sample taken at the entrance from each of 10 colonies started with package-bees.

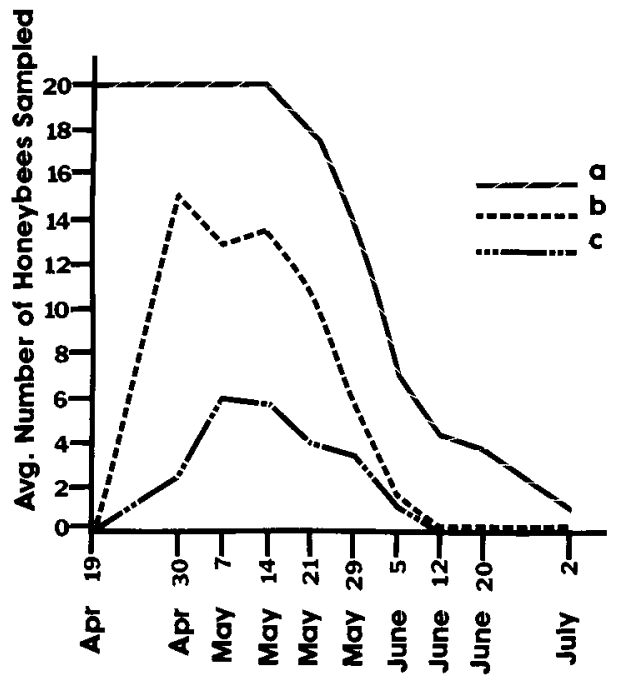

FIG. 2. - The number of yellow bees with nosematosis in colonies fed or not fed fumagillin in relation to the total yellow population.

a. Total yellow population

b. Yellow bees with nosema not fed fumagillin

c. Yellow bees with nosema fed fumagillin 


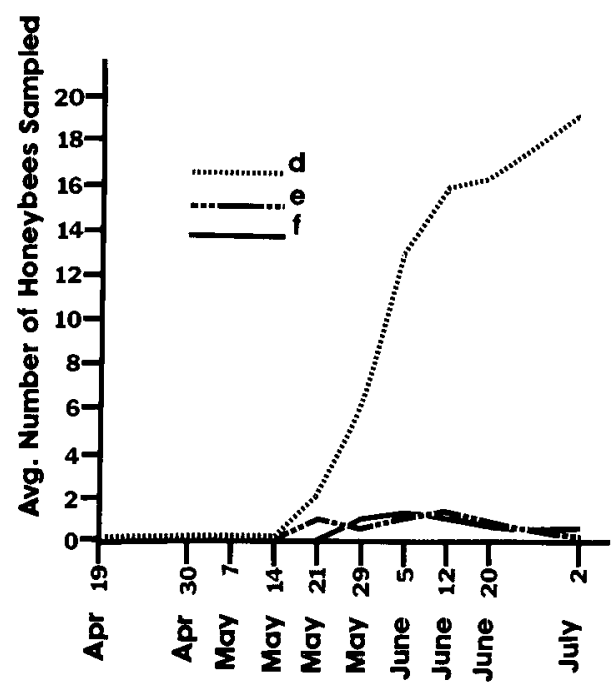

Fig. 3. - The number of black bees with nosematosis in colonies fed or not fed fumagillin in relation to the total black population.

d. Total black population

e. Black bees with nosema not fed fumagillin

f. Black bees with nosema fed fumagillin

Thus, only a small number of bees in the new population became infected with nosema because much of the nosema was eliminated with the death of the older bees, and the increasing numbers of newly emerged bees, which confirms MoELLER's dilution theory. One feeding of fumagillin did not eliminate infection in the new population though the rate of infection never exceeded $5 \%$ in the new population. A second feeding of fumagillin probably would have prevented any infection in the new population. In our test, about 43 days were required for the foraging population to reach $50 \%$ old and new bees in a colony started from a $31 \mathrm{~b}(1.36 \mathrm{~kg})$ package of yellow bees headed by a black queen.

Received for publication in A ugust 1978.

\section{ZUSAMMENFASSUNG}

BIENENWECHSEL UND SPIEGEL DER NOSEMASPOREN IN VÖLKERN, DIE AUS BIENENPAKETEN AUFGEBAUT WURDEN

Die Nosematose erreicht den Höhepunkt der Infektion im Frühjahr, weil sich die Bienen im Winter infolge beschränkter Flugmöglichkeit im Stock entleeren. In Völkern, die aus Bienenpaketen aufgebaut wurden, vermehrt sich die Nosema sehr rasch, denn die Bienen sind während des Transportes eingesperrt 
und die Population erhält in den ersten 3-4 Wochen nach Beginn der Eiablage der Königin keinen Nachschub an Jungbienen. MoELler (1972) zeigte, dass in überwinterten Völkern der Prozentsatz der mit Nosema infizierten Bienen absinkt, sobald im späteren Frühjahr Jungbienen schlüpfen und dass dadurch das Volk in die Lage versetzt wird, sich wieder zu erholen.

Wir prüften in unseren Versuchen die "Verdünnungstheorie " von MOELLER.

Wir bestimmten das Ausmass, in dem freigeschlüpfte Bienen nosemakrank wurden, stellten den Effekt der Behandlung mit Fumagillin fest und wir untersuchten, wie lange es dauert, bis in der Flugpopulation die alten Bienen von den Jungbienen abgelöst sind.

Für den Versuch wurden gelbe Bienen mit schwarzen Königinnen benutzt, um alte von jungen Flugbienen unterscheiden zu können. Alle Kunstschwärme wurden mit $54 \times 10^{6}$ Nosemasporen geimpft, um die Infektion sicherzustellen. In Käfigversuchen wurde mit gelben und schwarzen Bienen überprüft, dass zwischen diesen Stämmen kein Unterschied in der Empfindlichkeit gegenüber der Infektion besteht.

Nur eine kleine Zahl der Bienen in der jungen Population wurde mit Nosema angesteckt; das ist zurückzuführen auf die steigende Zahl frischgeschlüpfter Bienen - eine Bestätigung von MoELLER's Verdünnungstheorie - und auf die Ausscheidung der Nosemasporen aus dem Volk mit dem Abgang der älteren Bienen. Eine einzige Fütterung mit Fumagillin führte nicht zur völligen Eliminierung der Infektion; aber der Befallsgrad der Altbienen wurde drastisch gesenkt (fig. 2). In der jungen Population überstieg die Infektionsrate niemals $5 \%$. Eine zweite Fumagillinfütterung hätte wahrscheinlich jede Infektion in der neuen Population unterbunden.

In einem Volk, das mit einem Bienenpaket von $1,36 \mathrm{~kg}$ gelber Bienen und einer dunklen Königin gestartet wurde, dauerte es 43 Tage, bis die Flugbienen je zur Hälfte aus alten und aus jungen Bienen bestanden.

\author{
RESUMÉ \\ VARIATIONS DE LA POPULATION ET TENEURS EN SPORES \\ DE NOSEMA APIS DANS DES COLONIES DÉMARREES \\ AVEC DES PAQUETS D'ABEILLES
}

La nosémose atteint son maximum d'infection au printemps, parce qu'en hiver les abeilles défèquent dans la ruche en raison des périodes de vol limitées. Dans les colonies démarrées avec des paquets d'abeilles, Nosema se multiplie rapidement parce que les abeilles sont confinées pendant le voyage et que, durant 3 à 4 semaines après le début de ponte de la reine, aucune nouvelle abeille ne naît dans la ruche. Moeller (1972) a montré que le pourcentage d'abeilles contaminées par Nosema décroít dans les colonies qui ont hiverné, au fur et à mesure que de nouvelles abeilles naissent vers la fin du printemps.

Dans notre test nous avons approfondi la théorie de la dilution de MoEller, déterminé jusqu’à quel degré les abeilles adultes nouvellement écloses devenaient nosémeuses, évalué l'effet d'un nourrissement à la fumagilline et déterminé le temps nécessaire pour que la population de butineuses se renouvelle en jeunes abeilles.

On a utilisé des abeilles jaunes avec des reines noires afin de pouvoir distinguer les vieilles abeilles des jeunes. Pour obtenir avec certitude l'infection, on a inoculé $54 \times 10^{6}$ spores de Nosema à tous les paquets d'abeilles. Une étude en cage a été menée avec des abeilles jaunes et des noires afin de s'assurer qu'il n'y avait aucune différence de sensibilité entre les deux races. 
Un petit nombre seulement d'abeilles dans la nouvelle population a été contaminée par Nosema en raison du nombre croissant d'abeilles nouvellement écloses, ce qui confirme la théorie de la dilution de Moeller, et parce que beaucoup de spores de Nosema ont été éliminées par la mort des vieilles abeilles. Un nourrissement à la fumagilline n'a pas éliminé la contamination dans la population nouvelle, bien que le taux de contamination n'y aie jamais dépassé $5 \%$. Un second nourrissement à la fumagilline aurait vraisemblablement évité toute contamination dans la nouvelle population. Il a fallu environ 43 jours pour que la population de butineuses soit constituée pour moitié de jeunes abeilles dans une colonie démarrée avec un paquet de 3 livres $(1,36 \mathrm{~kg}$ ) d'abeilles jaunes possédant une reine noire.

\section{REFERENCE}

Moeller F. E., 1972. - Effects of emerging bees and of winter flights on nosema disease in honeybee colonies. J. Apic Res. 11 (2) : 117-120. 